\title{
Ni in Garnet Thermometry - A New Experimental Calibration at 3.0 - 4.5 GPa of Ni-Mg Exchange between Garnet and Olivine at Upper Mantle Pressures
}

\author{
Gregory M. Yaxley and Hugh St. C. O’Neill \\ Research School of Earth Sciences, The Australian National University, Canberra, Australia
}

\section{Introduction}

Cr-pyrope grains often recovered from heavy mineral concentrates (HMC) during diamond exploration programs are xenocrysts derived from accidental sampling of the lithosphere by very deeply-seated kimberlitic and related magmas. They are useful indicators of the possible proximity of deep mantlederived sources such as kimberlite, but they also contain records of the temperature at which they equilibrated with olivine in the upper mantle. This information is important as the temperature range of a population of $\mathrm{Cr}$-pyrope grains from particular pipes can be related to the local lithospheric geotherm at the time of kimberlite emplacement to estimate the extent to which the kimberlite has sampled the lithosphere at depths corresponding to the diamond stability field. Kimberlites which have sampled extensively at depths within the diamond stability field are clearly more attractive exploration targets than those which have predominantly sampled the shallower graphite stability field.

The temperature information in Cr-pyrope xenocrysts is preserved because olivine and garnet participate in temperature dependent exchange of $\mathrm{M}^{2+}$ metal cations (where $\mathrm{M}=\mathrm{Fe}, \mathrm{Mg}, \mathrm{Ni}, \mathrm{Zn}$, Co etc);

$$
\mathrm{M}_{2} \mathrm{SiO}_{4}+\mathrm{Mg}_{3} \mathrm{Al}_{2} \mathrm{Si}_{3} \mathrm{O}_{12}=\mathrm{Mg}_{2} \mathrm{SiO}_{4}+\mathrm{M}_{3} \mathrm{Al}_{2} \mathrm{Si}_{3} \mathrm{O}_{12}
$$

If the P-T dependence of these exchange reactions can be calibrated, then the compositions of coexisting upper mantle olivine and garnet can be used to determine their equilibration temperatures. Because the $\mathrm{Ni}$ content of mantle olivine is fairly constant at about $2,900 \pm 360 \mathrm{ppm}$ (1s) (Ryan et al. 1996), the calibration of the olivine-garnet $\mathrm{Ni}$ exchange equilibrium can be applied to single grain garnet xenocrysts, inferred to have been in equilibrium with olivine with this $\mathrm{Ni}$ content (Griffin et al. 1989; Ryan et al. 1996).

Distribution of Ni between garnet and olivine has been calibrated both empirically by Griffin et al. (1989) and Ryan et al. (1996) by applying conventional multiphase geothermometers to natural garnet peridotite xenoliths and regressing a correlation between calculated temperature and garnet $\mathrm{Ni}$ content. In addition, Canil
(1994) performed an experimental calibration at 6-8 GPa using a multi-anvil high pressure apparatus. Although there is agreement between the empirical and experimental calibrations in the $900-1000^{\circ} \mathrm{C}$ temperature range, there are significant discrepancies outside this range.

\section{Methods}

We have conducted an additional experimental calibration using piston-cylinder apparatuses at 3.0-4.5 $\mathrm{GPa}$. The experiments were conducted using a finely ground sintered oxide starting composition (dB-1) designed to crystallise at high $\mathrm{P}$ and $\mathrm{T}$ assemblages containing garnet + olivine of broadly similar compositions to the natural phases present in the lithosphere. In order to facilitate precise analysis of the $\mathrm{Ni}$ content of run products by electronprobe microanalysis, the starting material contained $5 \mathrm{wt} \%$ $\mathrm{NiO}$, considerably higher than natural $\mathrm{Ni}$ abundances in the upper mantle. The validity of this approach in terms of Henry's Law behaviour was demonstrated by Canil (1994).

The sintered dB-1 mix was used in synthesis experiments at $3.0 \mathrm{GPa}$ and various temperatures. These experiments were run either in large capacity $(\approx 100 \mathrm{mg}$ ) graphite capsules sealed in platinum, or in $\mathrm{Au}$ capsules, sealed by arc welding. In the Au capsule experiments, a few wt $\%$ deionised $\mathrm{H}_{2} \mathrm{O}$ was sometimes added to promote reaction and equilibration. This material was liberated from the capsule post-run. Small fragments were mounted in epoxy and polished for examination of back-scattered electron images and analysis by WDS electronprobe. The run products of the synthesis experiments were garnet + olivine bearing assemblages. The remainder of the material was then ground to a very fine grain size under acetone, dried and then used in subsequent equilibration experiments at high pressures and temperatures.

Equilibration experiments using the pre-synthesised crystalline dB-1 material were conducted in a conventional $1.27 \mathrm{~cm}$ piston-cylinder apparatus. Capsule materials included graphite sealed in $\mathrm{Pt}$, sealed $\mathrm{Au}$ with no internal graphite capsule, and $\mathrm{Ni}_{95} \mathrm{Fe}_{05}$ 
alloy. In some low temperature $\left(\leq 1200^{\circ} \mathrm{C}\right)$ runs using sealed $\mathrm{Au}$ capsules, a few wt $\% \mathrm{H}_{2} \mathrm{O}$ were added using a microsyringe to promote reaction and a faster approach to equilibrium.

This approach of pre-synthesis followed by equilibration experiments allowed rigorous bracketing of the exchange reaction, by allowing phases to approach equilibrium at a particular temperature from opposite directions by using material synthesised at temperatures above and below that temperature.

Experimental run products were analysed by WDS electronprobe microscopy using an accelerating voltage of $15 \mathrm{kV}$ and beam current of $20 \mathrm{nA}$ on the RSES Cameca SX-100.

\section{Results}

The anhydrous experiments in $\mathrm{Pt} /$ graphite or $\mathrm{Ni}_{95} \mathrm{Fe}_{05}$ capsules resulted in fine-grained $(\approx 10 \mu \mathrm{m})$ assemblages of garnet + olivine, in some cases with lesser amounts of orthopyroxene and very fine grained spinel (Figure 1A). At $3.0 \mathrm{GPa}$ and $1500^{\circ} \mathrm{C}$, anhydrous runs exhibited evidence of partial melting, with interstitial patches of aluminous, low $\mathrm{Mg} \#$ clinopyroxene and other materials inferred to be metastable products formed from liquid during quenching. Mineral phases were generally homogeneous and no evidence of unreacted oxide material from the starting mix was observed.

Water bearing runs (Au capsules) were run at 3.0-3.5 $\mathrm{GPa}$ and $1000-1200^{\circ} \mathrm{C}$ and crystallised relatively coarse grains (up to $\approx 30 \mu \mathrm{m}$ ) of olivine and garnet and sometimes minor orthopyroxene. Some $\mathrm{H}_{2} \mathrm{O}$-bearing runs runs (e.g. C-2093 and $\mathrm{C}-2112$ at $1075^{\circ} \mathrm{C}$ and $1150^{\circ} \mathrm{C}$ respectively) also contained pools of quenched melt (Figure 1B).

Olivine $\mathrm{Mg \#}$ varied from 91.1 to 98.4 with forsterite content (Fo) varying from 83.6 to $95.2 \mathrm{~mol} \%$. Ni mole fraction varied from 0.014 to 0.081 . Garnet $\mathrm{Mg \#}$ varied from 85.4 to 90.8 , with grossular component varying from 0.025 to 0.141 .

The distribution of $\mathrm{Ni}$ and $\mathrm{Mg}$ between olivine and garnet can be expressed by the coefficient

$$
\mathrm{K}_{\mathrm{d}}=[\mathrm{Ni} / \mathrm{Mg}]_{\mathrm{ol}} /[\mathrm{Ni} / \mathrm{Mg}]_{\mathrm{ga}}(1)
$$

$\mathrm{LnK}_{\mathrm{d}}$ correlates linearly with inverse absolute temperature as can be seen in Figure 2.

\section{Discussion}

The Ni/Mg partitioning data from 17 experiments (synthesis and equilibration) were fitted using a least squares routine to the equation

$$
\mathrm{LnK}_{\mathrm{d}}=-\Delta \mathrm{H} / \mathrm{RT}+\Delta \mathrm{S} / \mathrm{R}-\mathrm{P} \Delta \mathrm{V} / \mathrm{RT}(2)
$$

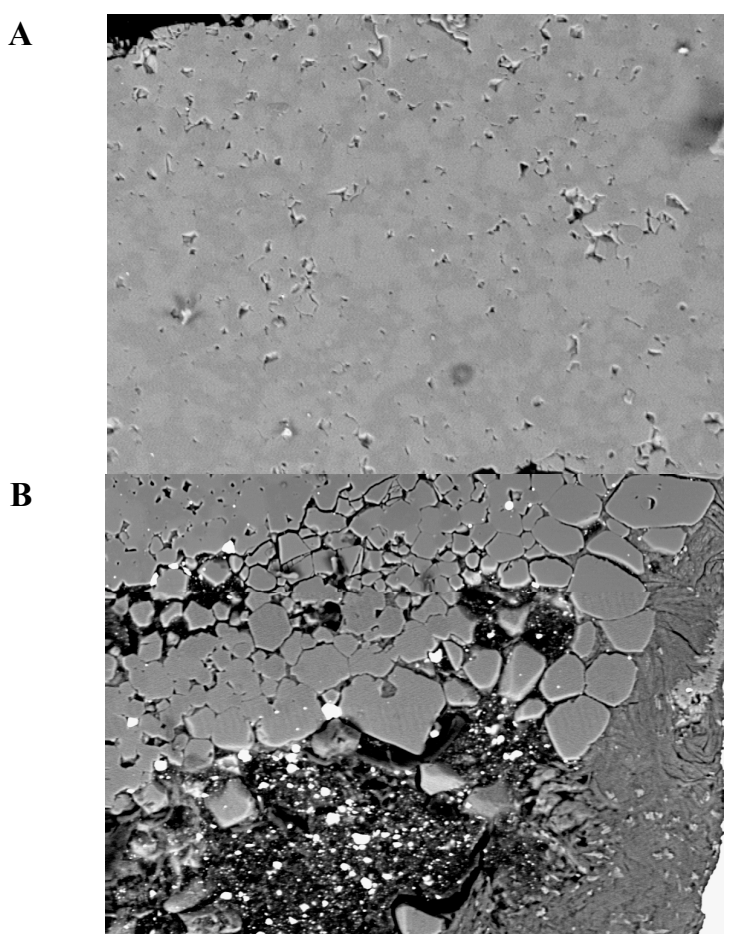

Figure 1: Back-scattered electron images of (A) run C$2087\left(3.0 \mathrm{GPa}, 1100^{\circ} \mathrm{C}\right)$, an anhydrous synthesis run conducted in a $\mathrm{Au}$ capsule showing fine-grained assemblage of olivine and garnet. The olivine is the brighter phase mainly due to its relatively high $\mathrm{Ni}$ abundance, (B) run C-2093 (3.0 GPa, $\left.1150^{\circ} \mathrm{C}\right), \mathrm{a} \mathrm{H}_{2} \mathrm{O}-$ bearing equilibration run using the material synthesised in C-2087, showing relatively large crystals of olivine and garnet, with a quenched melt pool at the bottom right corner of the image. The field of view for both is approximately $250 \mu \mathrm{m}$ across.

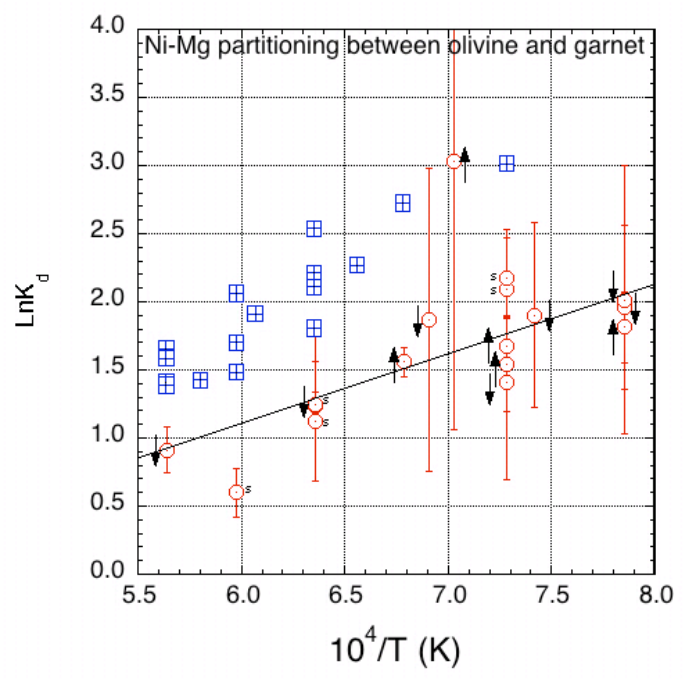

Figure 2: Plot of $\ln \mathrm{K}_{\mathrm{d}}$ vs $10^{4} / \mathrm{T}\left(\mathrm{K}^{-1}\right)$ for the current experiments (red circles with $2 \sigma$ error bars) and for those of Canil (1994) (blue squares). Experiments marked $s$ are synthesis runs. Arrows against equilibration runs indicate the direction from which equilibrium was approached. Black line is linear least squares regression through the current data. 
The pressure term in expression 2 is of insignificant magnitude over the range of pressures of the current experiments, i.e a pressure effect was not resolved within experimental uncertainty, and was therefore not included in the derivation of the following algorithm.

$$
\mathrm{LnK}_{\mathrm{d}}=5264 \pm 589 / \mathrm{T}-2.065 \pm 0.405 \chi^{2}=2.24 \text { (3) }
$$

No dependence of $\ln _{\mathrm{d}}$ on mole fraction of $\mathrm{Ni}$ in olivine was detected, even for olivines containing several wt\% NiO, consistent with Henry's Law behviour, as discussed by Canil (1994). Similarly, no dependence of $\ln _{\mathrm{d}}$ on other olivine or garnet compositional parameters was resolvable.

When expression (3) was used to calculate experimental run temperatures, the nominal run temperatures were reproduced within $\pm 100^{\circ} \mathrm{C}$ for most experiments. Thus $\pm 100^{\circ} \mathrm{C}$ is considered a reasonable estimate for the uncertaintly of this thermometer.

In order to be useful for single grain thermometry, an alternative thermometer has been formulated, by regressing inverse absolute run temperature and $\ln \mathrm{D}_{\mathrm{Ni}}$ where $\mathrm{D}_{\mathrm{Ni}}=\mathrm{Ni}_{\mathrm{ga}} / \mathrm{Ni}_{\mathrm{ol}}$. The resultant empirical expression is as follows;

$$
\mathrm{T}(\mathrm{K})=10^{4} /\left(5.0495-0.807 \ln \mathrm{D}_{\mathrm{Ni}}\right)(4)
$$

This thermometer requires an assumed olivine $\mathrm{Ni}$ content of 2900 ppm following Ryan et al. (1996) and reproduces the nominal experimental temperatures within $100^{\circ} \mathrm{C}$ in all but 3 experiments, and within $50^{\circ} \mathrm{C}$ for more experiments.

The partitioning relationships obtained from these experiments at 3.0-4.5 GPa are clearly different from those of Canil's (1994) higher pressure study (6.0-8.0 $\mathrm{GPa}$ ) (Figure 2). This is believed to reflect a real pressure effect on the partitioning reaction of $\approx 6$ $8^{\circ} \mathrm{C} / \mathrm{kbar}$, and is unlikely to be due to lack of equilibration in our experiments nor in those of Canil (1994). This is because both studies have successfully included reverals of the exchange equilibrium.

In Figure 3 we have applied the Ryan et al. (1996), Canil (1994) and the current Ni in garnet thermometers to data from a suite of garnet peridotite xenoliths from the North China Craton and Sulu Ultrahigh pressure terrane (Zheng et al. 2006). We have plotted the equilibration pressure of the xenoliths, calculated from the Al-in-opx barometer of Brey and Kohler (1990) (P[BK90]), against the difference between the xenoliths' temperatures calculated from the Ca-in-opx thermometer of Brey and Kohler (1990) (T[BK90]) and the various calibrations of the $\mathrm{Ni}$-in-garnet thermometer. This is a crude test of the presence or absence of a pressure effect in the Ni exchange reaction between garnet and olivine.

From Figure 3, the temperature discrepancies for all three calibrations depend positively on pressure. Temperatures calculated using the current calibration of the Ni-in-garnet thermometer ( $[\mathrm{Y}-\mathrm{O}])$ agree well

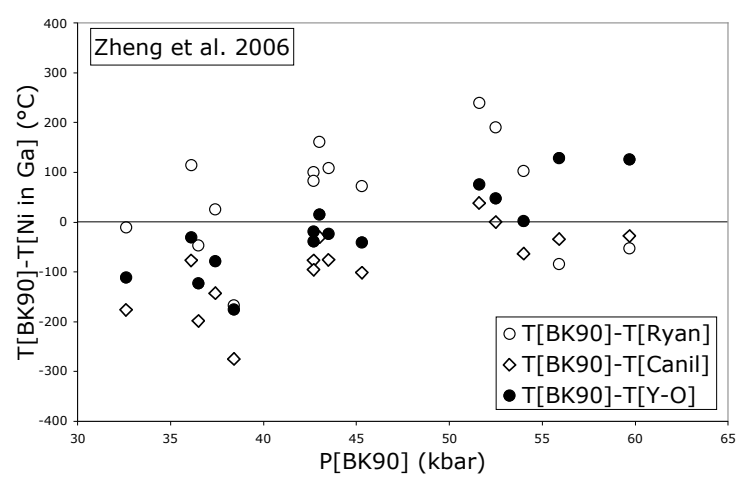

Figure 3: Plot of pressure (Brey and Kohler 1990) versus discrepancy between temperatures calculated using the Ca-in-opx thermometer (Brey and Kohler 1990) and various $\mathrm{Ni}$ in garnet thermometers for garnet peridotites from China (Zheng et al. 2006).

with $\mathrm{T}[\mathrm{BK} 90]$ overall (mostly within $\approx 100^{\circ} \mathrm{C}$ ), but particularly at pressures similar to those at which the calibration experiments were run (30-45 kbar). Temperatures calculated using the Canil (1994) calibration agree with T[BK90] best at higher pressures nearer to those of the calibration experiments $(>50$ kbar), but are often significantly lower at $\mathrm{P}<40$ kbar. Temperatures calculated using the Ryan et al. (1996) calibration (T[Ryan]) mostly but not exclusively exceed T[BK90] over the full pressure range. These trends are broadly consistent with a pressure effect on the Ni partitioning reaction between olivine and garnet and emphasise the need for a full experimental calibration over the entire relevant pressure range.

\section{References}

Brey, G.P. and Köhler, T., 1990. Geothermobarometry in four-phase lherzolites II. New thermobarometers, and practical assessment of existing thermobarometers, Journal of Petrology, 31, 1353-1378.

Canil, D., 1994. An experimental calibration of the „nickel in garnet“ geothermometer, Contributions to Mineralogy and Petrology, 117, 410-420.

Griffin, W.L., Cousens, D.R., Ryan, C.G., Sie, S.H. and Suter, G.F., 1989, Ni in Cr-garnet, a new geothermometer, Contributions to Mineralogy and Petrology, 103, 199-202.

Ryan, C.G., Griffin, W.L. and Pearson, N.L., (1996), Garnet geotherms: pressure-temperature data from Cr-pyrope garnet xenocrysts in volcanic rocks, Journal of Geophysical Research, 101, 5611-5625.

Zheng, J., Griffin, W.L., O’Reilly, S.Y., Yanh, J., Li, T., Zhang, M., Zhang, R. and Liou, J.G., (2006), Mineral chemistry of peridotites from Paleozoic, Mesozoic and Cenozoic lithosphere: Constraints on mantle evolution beneath eastern China, Journal of Petrology, 47, 2233-2256. 
